\title{
ASSESSMENT OF COMPOST QUALITY OF SERICULTURE WASTE ON THE GROWTH OF Anogeissus leiocarpus USING TWO COMPOSTING METHODS
}

\author{
${ }^{* 1}$ Kambai, C., ${ }^{2}$ Olatunji, R. O. and ${ }^{3}$ Francis, M. J.
}

\begin{abstract}
${ }^{*}$ Department of Forestry Technology, Federal College of Forestry, Jos, Plateau state, Nigeria. *Phone:08065359325Email: talk2nev@yahoo.com; kambai.c@frin.gov.ng

${ }^{I}$ Department of Forestry Technology, Federal College of Forestry, Jos, Plateau state, Nigeria Phone: 09028533461 Email: olusina2209@gmail.com

${ }^{2}$ Department of Forestry Technology, Federal College of Forestry, Jos, Plateau state, Nigeria

Phone: 08083774225 Email: mundi_fancis@yahoo.com
\end{abstract}

\begin{abstract}
This study investigated the compost quality of sericulture waste on the growth of Anogeissus leiocarpus using two composting methods. The two-method adopted were M1 (pile method) and M2 (bin method). Sericulture waste which includes mulberry leaves and silkworm excreta were air dried for 24hours, measured $(1 \mathrm{~kg})$ and set in layers for both methods adopted. Samples of compost from each method were taken before planting to the laboratory for proximate analysis. Descriptive statistics and analysis of variance (ANOVA) were used to analyze the data obtained. Anogeissus leiocarpus seeds were soaked for 10 minutes at $35^{\circ} \mathrm{C}$ and at $9.5^{\circ} \mathrm{C}$ for 24 hours to enhance the breaking of its dormancy. Anogeissus leiocarpus seeds was planted using sericulture compost from both adopted methods. Result shows that M1 had the highest mineral composition. M1 recorded the highest (N \%) with the value of $0.93 \%$; (P \%) with $0.089 \%$; $(\mathrm{K} \%)$ with $0.58 \%$; $(\mathrm{Ca} \%)$ with the value of $1.78 \%$ and $(\mathrm{Mg} \%)$ with the value of $0.72 \%$ while $\mathrm{M} 2 \mathrm{had}$ a lower mineral composition. The result obtained for the early growth parameters shows that M1 had a higher plant height and stem girth which was significantly different from M2, the mixture of the two compost had the highest leaf count which was also significant while the control recorded the lowest value for all the parameters assessed. This result suggests that pile composting method is the best method for composting sericulture waste and can be used as a good and preferable alternative for inorganic manure in raising seedlings and trees species. Adopting the use of sericulture waste as compost will help in reducing the waste management problem, enhance economic use of farm waste and also help to ease the low germination rate and germination percentage of Anogeissus leiocarpus.
\end{abstract}

Keywords: Anoigesus leiocarpus, Compost, Growth, proximate, Sericulture

LICENSE: This work by Open Journals Nigeria is licensed and published under the Creative Commons Attribution License 4.0 International License, which permits unrestricted use, distribution, and reproduction in any medium, provided this article is duly cited.

COPYRIGHT: The Author(s) completely retain the copyright of this published article.

OPEN ACCESS: The Author(s) approves that this article remains permanently online in the open access (OA) mode.

QA: This Article is published in line with "COPE (Committee on Publication Ethics) and PIE (Publication Integrity \& Ethics)". 


\section{INTRODUCTION}

Compost is the breaking down of organic waste into humus that can be reused as beneficial nutrient rich resources for organic soil amendments. Composting is the decomposition of plant remains and other once-living materials to make an earthy, dark, crumbly substance that is excellent for adding to house plants or enriching garden soil. It is a key ingredient in organic fanning. At the simplest level, it is the process of composting a heap of wetted organic matter (leaves, green food waste) and waiting for the materials to breakdown into humus after a period of weeks or months. Compost can be rich in nutrients, it is used in gardens, landscaping, horticulture and agriculture (Bucido, 2005). The compost itself is beneficial for the land in many ways, it could be used as a soil conditioner, a fertilizer addition of vital humus or humic acids and as a natural pesticide for soil in ecosystems. Compost is useful for erosion control and landfill cover. Organic ingredients intended for composting can alternatively be used to generate biogas through anaerobic digestion. Anaerobic digestion is fast overtaking composting in some parts of the world (Robert, 1997).

Composting is a major way of recycling yard and kitchen waste and a critical step in reducing disposal. It is the product of the controlled biological decomposition of organic materials. Most especially, compost is the stable, humus-like product resulting from the biological decomposition of organic matter under controlled conditions. Another commonly accepted composting definition is that of the National Organic Standard Board (NOSB), which states that composting is a process in which organic matter of plant and or animal origin is managed to achieve aerobic decomposition and an increase in temperature in order to enhance its physical and nutritive properties as a soil amendment while minimizing pathogenic organisms. (NOSB, 2006). Human control of the biological decomposition process is what differentiates composting from the natural decomposition of organic matter. Organic materials are recycled regardless of whether or not we compost them, but regulating and optimizing conditions ensure a faster process and the generation of a quality and product (Rodale, 1993).

Anogeissus leiocarpus is a tree of up to $30 \mathrm{~m}$ in height, typically $15-18 \mathrm{~m}$ with light green foliage than trunk is wider at the base and sometimes stripped. The crown is dense and the branches with age and fibrous with this scale. The stems are finally pubescent. Leaves are alternate to sub opposite, elliptic to ovate-lanceolate in shape and 2-8cm long and 1.5-3.5 across. The leaves are acuminate or mucronate at the apex and cuneate at the base. The petiole is $6 \mathrm{~mm}$ long. Individually growing in diner areas tends to have smaller leaves and hairier flowers. The inflorescence is a spherical, axillary and terminal duster. The yellow green scented flowers are brownish orange at the center and with white hairs. The flowers are bisexual, apetalus, 5-6mm in diameters and with 10 stamens.

The wood of Anogeissus leiocarpus is well appreciated as a carving wood and it is used for construction and tool handle because it is fairly insect and termite resistant. It has yellowish sapwood and a dark brown black core. It is important for firewood and charcoal production. The ashes are used for tanning leathers and the leaves and bark are used as yellow dyes for fabric and leather. The gum is used to make ink and more viscous or to glue lather and is used occasionally as Arabic gum replacement. The roots are used as chew sticks for cleaning teeth and the leaves as fodder for small ruminant. Leaves, roots and trunk back are used by traditional practitioners for the treatment of helminthasis, trypanosomiasis, malaria and dysentery. Other medicinal use includes treatment for diarrhea, fever, cough pneumatism, leprosy, wounds and sin diseases. 


\section{SERICULTURE}

Sericulture is the rearing of silkworms for the production of silk. Although there are several commercial species of silkworms, Bombyxmori (Linnaeus, 1758) is the widely used and intensively studied silkworm. Generally, in sericulture farms, the left-over mulberry leaves from rearing bed and field and other waste including silk worm litter which are been generated on the farm are not properly utilized. Hence, it is sentinel to convert the sericulture farm waste into valuable compost by adopting suitable composting technology. It belongs to Moraceae, a family of deciduous or evergreen trees and shrubs often climbing, mostly of pantropical distribution and characterized by milky sap. Several general bear edible fruit e.g. Morus [true mulberries). The related hemp family, whose plant do not contain latex, were formerly included in these family (Cherry, 1993).

Mulberry sericulture consists of three major aspects: moriculture, cocoon production and silk reeling. Moriculture involves the cultivation of mulberry plants to produce leaves used as food for silkworms, while cocoon production involves controlled rearing of silkworm to produce quality cocoons. Silk reeling, on one hand involves unwinding of silk filament from the cocoon with raw silk as the end product. In all these aspects of sericulture, a considerable volume of waste is generated (Agric Business, 2011; Gahlot \& Suryanarayana, 2008).

Silk fiber is protein produced from the silk glands of silk worms. The technique of silk production is known as sericulture; it is an agro-industry and is playing an important role in the economic development of silk rearing pockets of rural dwellers in India, providing gainful occupation to the less privileged. India is the second largest producer of silk in the world after China and has the distinction of producing all the four types of silk which are mulberry silk (91.7\%), Tasar silk (1.4\%), Eri-silk (6.4\%) and Muga silk (5\%), which are produced by different species of silk worms (Itol et al., 1995).

Though various research work have been carried out to address land degradation and to reduce the effect of irreparable damage that have been done in many instances to our environment through activities such as uncontrolled deforestation, pollution, ozone layer destruction, and desertification, bad land use practices leading to erosion, indiscriminate discharge of both liquid and solid waste to the environment, little have been known on how to use farm waste to enhance the production of tree seedlings in order to meet the high demand for plantation establishment (Cherry, 1993). A farm establishment produces many types of waste in its daily operation. Larger percentage of this waste emanates from both plant and animal production or during processing or conversion of these product into finished product. These wastes contribute to air, waste, and land pollution through repugnant and repulsive choky smell (Margaret, 1998). Farm wastes play a significant role in enriching the soil, maintaining the water and climatic cycle, humidity, precipitation, recycling and conversion of waste minerals into nutrients.

The cost of "organic waste management planning and implementation continue to increase. Current waste disposal option, have their own limitation and their own environmental problem, transporting waste to more remote area for disposal is a temporary and expensive solution for many urban and rural centers. Recently, there have been many environmental and health concerns over the disposal of farms and agricultural waste. High concentration of sericulture waste in farm area has resulted in contamination of aquifers and wells that supply drinking water to surrounding communities. (Agunwarnba \& Ogwueleka, 2003). 


\section{STATEMENT OF THE PROBLEM}

Improper disposal of sericulture waste has been linked to numerous deaths and illness due to high concentration in small presence of deadly pathogens (Dutta, 2006) that have poisoned drinking water, land spreading that pollutes streams and aquifer with nitrates and phosphates. However, Good waste management on farm is essential to ensure a healthy, safe, productive farming enterprise. Farmer's inappropriate disposal waste can cause contamination and pollution. Hence, there is an urgent need to look for alternative ways of using sericulture waste to improve degraded soils, enhance seedling production at the nursery stage and improve production of tree seedlings in order to meet the high demand for plantation establishment. Anogeissus leiocarpus which are known to possess difficulty in growth because it has a very slow initial growth, low re-growth ability and is very sensitive to bush fire and uncontrolled deforestation in its natural Savannah habitat. (Sacande and Sanogo, 2007). These factors, in addition to the poor germination of its seeds are adverse factors for long term conservation and sustainable uses of the species (seed leaflet No.119 September 2007). And although this species is in high demand by many communities; its planting remains limited by its very low seed germination rate of less than $5 \%$. This has been confirmed by several studies over the last twenty years. (Some et al., 1989; Kambou, 1997; Dias, 2006; Bognounou et al., 2010). Some of these studies suggested that low germination of Anogeissus leiocarpus is due to a large proportion (around 90\%) of non-fertile seeds and in this infertility caused by floral abortion is noticeable by the absence of embryo's in many seeds (Some et al., 1989; Kambou, 1992).

\section{AIM AND OBJECTIVES OF THE STUDY}

The aim of this research is to determine the effect of two different composting methods on compost quality of sericulture waste and its effect on the growth of Anogeissus leiocarpus.

However, the specific objectives of the study are as follow to;

1. examine the mineral composition in the sericulture waste.

2. determine the effect of composting sericulture waste on the early growth parameter of Anogeissus leiocarpus.

\section{JUSTIFICATION}

Due to long term adverse effect of inorganic fertilizer on human health, the present emphasis is on the use of readily available, environmentally friendly and cost-effective fertilizers, one of which is organic fertilizer. Fertilization has therefore become a practical tool for rapidly increasing growth of trees species especially in developed countries, to provide good nursery stock. Also, major irreparable damages have been done in many instances to our environment through indiscriminate disposal of both liquid and solid waste as well as the inability of the communities to control or manage the sericulture waste. As the solid waste quantities are increasing in all cities and towns due to various human activities, there is an increasing concern about the economic viability and environmental compatibility of the current waste management methodologies (Kan, 2009). The overwhelming environmental concerns regarding animal waste have been focused on nutrient accumulation in the arable soil profile, contamination of surface and groundwater and ammonia emission into the atmosphere (Mulla et al., 2001). Persistent contaminants in the environment affect human health and ecosystems. There is an urgent need by the Government, producers, and society to puffer waste disposal solution that is economical and efficient and does not add further environmental pressure to the growing world. The practical solution required to the farm waste 
management is basically finding ways to use them as alternative to inorganic fertilizer to raise and improve tree seedlings. Using compost can reduce the need for inorganic fertilizers and pesticides. It serves as a marketable commodity and is a low-cost alternative to standard landfill cover and artificial soil amendment. Compost provides excellent nutrition for plants, builds the soil, feeds beneficial microbes and keeps valuable resources out of landfills (Ashiru, 1986).

\section{MATERIALS AND METHODS STUDY AREA}

The experiment was carried out at Plant nursery of Federal College of Forestry Jos, Plateau State. It lies within the Northern Guinea Savannah zone of Nigeria, It is on latitude $9^{\circ} 36^{\mathrm{r}} \mathrm{N}$ and longitude $9^{0} 14^{\prime} \mathrm{E}$ of the equator and cover a land area of $1,695 \mathrm{~km}^{2}$ with an average altitude of about 1,200metres above sea level. It enjoys a fairlymoderate annual rainfall, characterized by two reasons; dry and wet season, and minimum annual rainfall of $1179.02 \mathrm{~mm}$ with an average temperature of $22^{\circ} \mathrm{C}$. (Plateau State Government Diary, 2003).

\section{METHOD}

Pile Method (MI): The sericulture waste collected was air dried for 24 hours before $1.0 \mathrm{~kg}$ was measured with a weighing balance. It was arranged in form of heap, $50 \mathrm{ml}$ of water was sprinkled over the layer taken daily. The compost layer was turned at interval of three days. Aerobic composting was practiced in this method of composting i.e. composting in the presence of air. This composting method does not emit unpleasant odor.

Bin Method (M2): The sericulture waste collected was air dried for 24 hours before $1.0 \mathrm{~kg}$ was measured with a weighing balance and arranged in layers as well into a bin of convenient size. $50 \mathrm{ml}$ of water was sprinkled over the layers. The layer of the compost was turned at the interval of three days. Anaerobic composting was practiced in this method of composting i.e. which simply mean slim composting, compost was with little air, emits awful smell.

\section{DATA COLLECTION}

Immediately, the compost is cured, Anogeissus leiocarpus seeds was sown inside the germination tray which was made up to two (2) head pan of topsoil and one (1) headpan of sharp sand mixed with compost separately. The germination tray for the control had two (2) head pan of topsoil mixed with one (1) headpan of sharp only. Readings was taken immediately after planting on weekly basis for growth parameters such as; number of leaves, stems girth and plant height.

\section{PROPAGATION}

The seed was planted into the already prepared germination tray which comprises of sharp sand, top soil, and the compost. Inside each germination tray, 10 seeds were soaked for 24 hours at $9.5^{\circ} \mathrm{C}$ of water, after which they were planted in the trays containing the bin and pile compost respectively while 10 seeds were soaked $35.5^{\circ} \mathrm{C}$ and planted into the tray containing the mixed pile and bin compost and the control. In the absence of rainfall, the seed were watered once in a day with $100 \mathrm{ml}$ of water only in the morning. 


\section{METHOD OF DATA ANALYSIS}

The result of the data analysis was subjected to means and analysis of variance (ANOVA). Independent T-test was used to analyze temperature of the two composting methods.

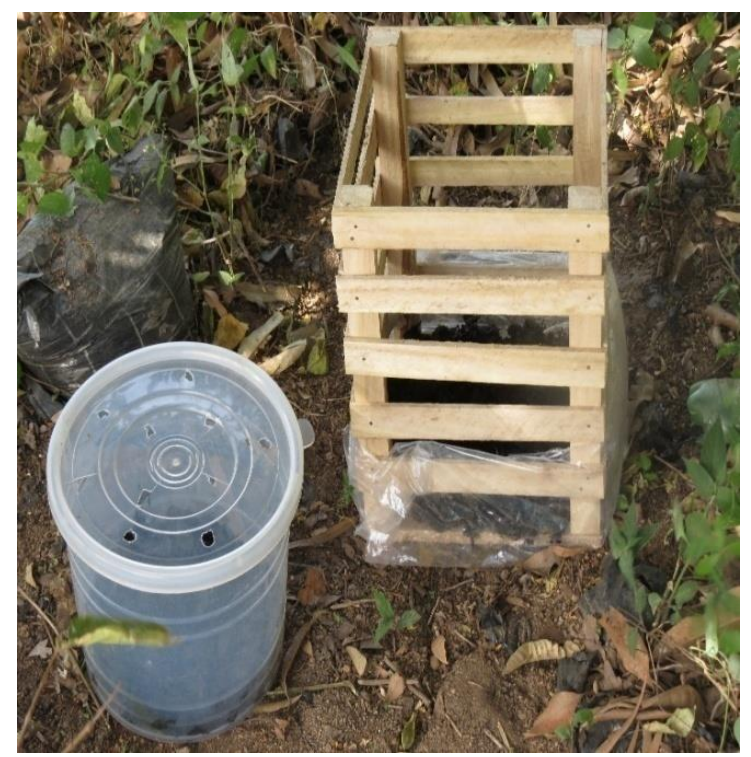

Plate 1: Pile and Bin composting methods

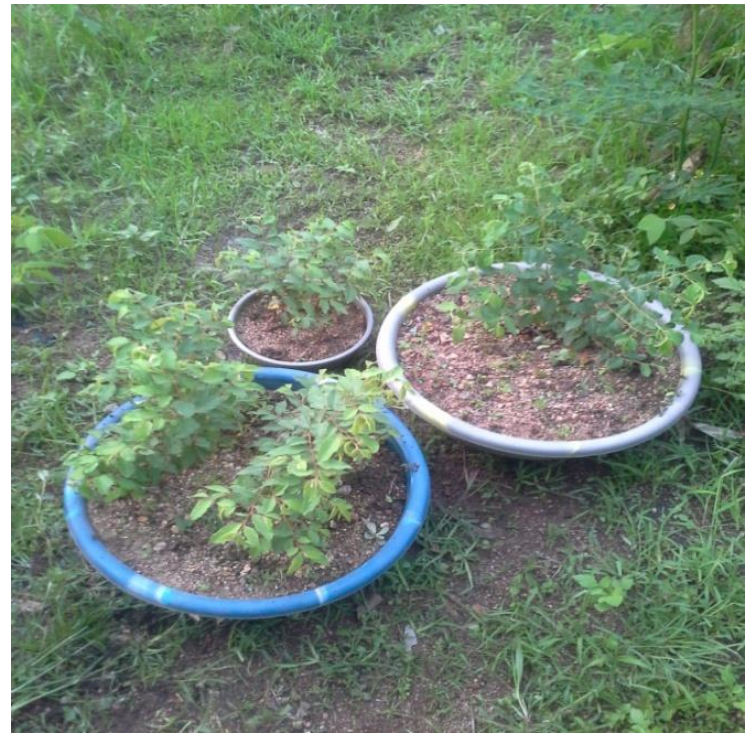

Figure 2: A. leiocarpus seedling growing in the pile, bin and pile-bin compost

\section{RESULT}

Figure 3 below shows the percentage Nitrogen content for pile compost was $0.93 \%$ while Bin compost was $0.83 \%$.

Percentage Nitrogen of pile compost was higher than Bin compost.

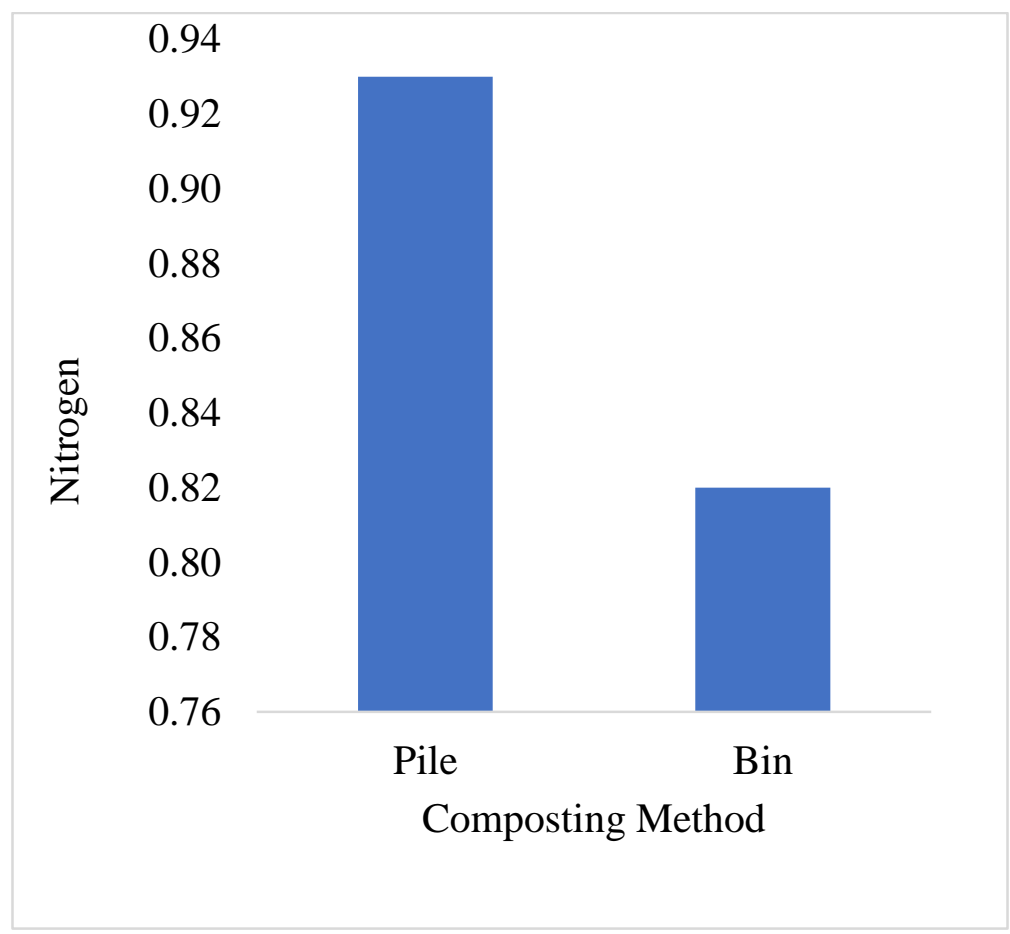

Figure 3: Percentage Nitrogen content of the two composting methods 
The Figure 4 indicates the Phosphorus content of Pile compost was $0.89 \%$ whereas the Bin compost had $0.82 \%$. Phosphorous content of pile compost was higher than Bin compost.

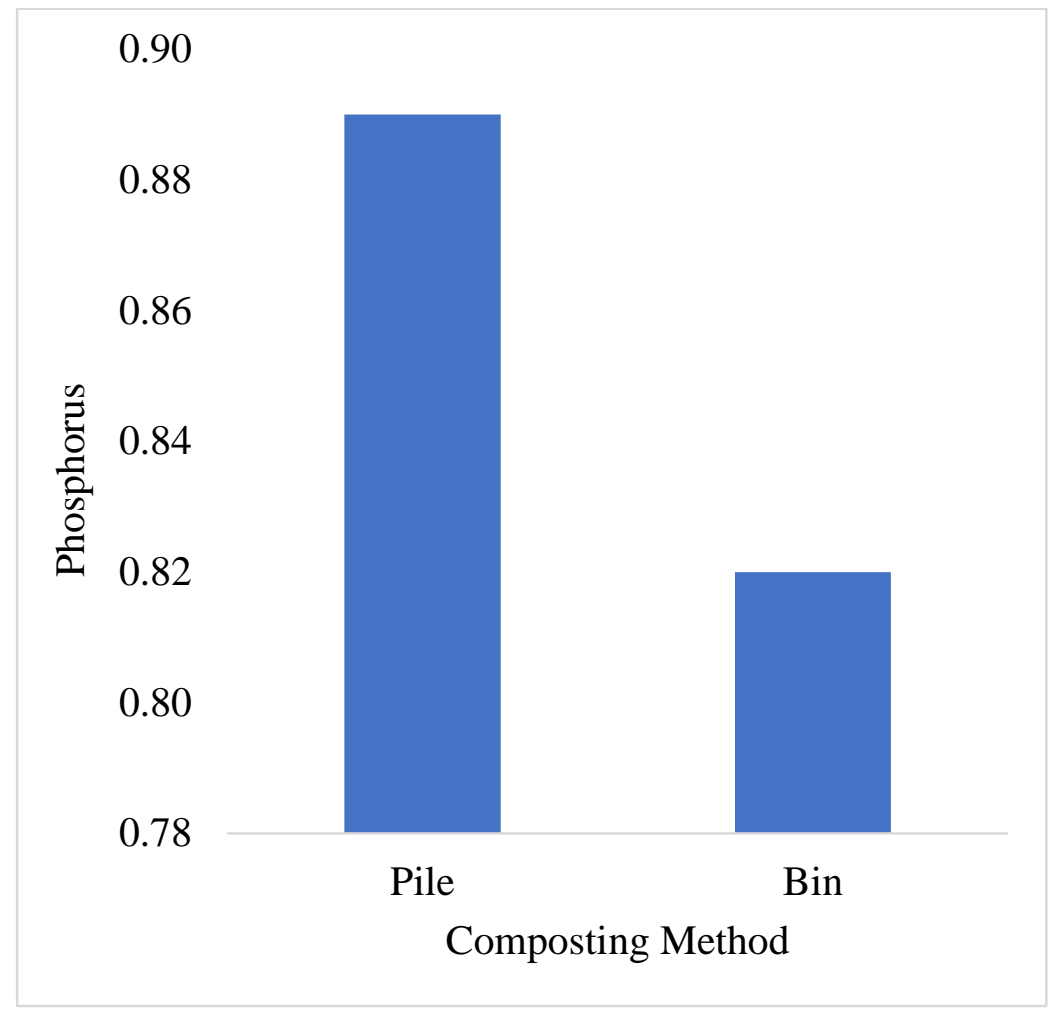

Figure 4: Phosphorus content of the two composting methods

Figure 5 below indicates that the Potassium of the Pile compost was $0.58 \%$ and the Bin compost was $0.51 \%$. Potassium content of pile compost was higher than Bin compost.

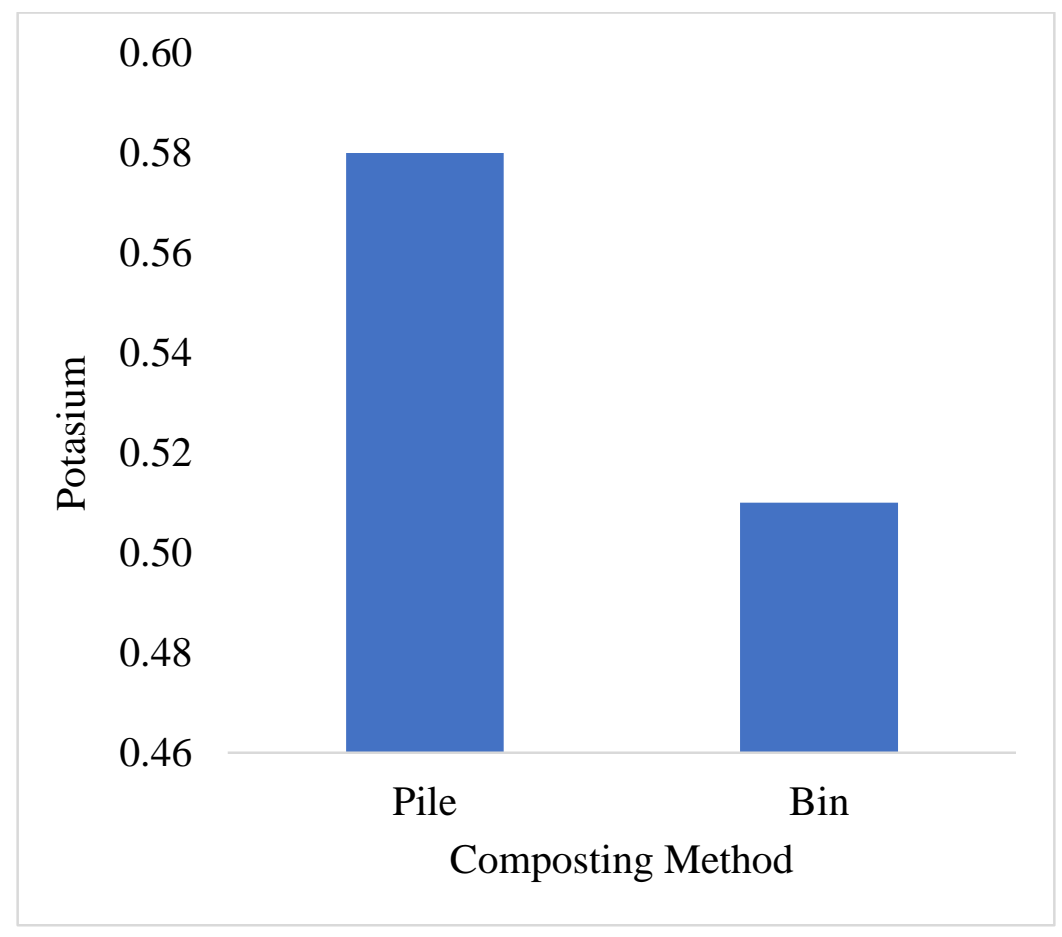

Figure 5: Potassium content of the two composting methods 
Figure 6 illustrates that the Magnesium content for Pile compost was $0.72 \%$ while the Bin compost was $0.64 \%$. Magnesium content of pile compost composting was higher than Bin compost.

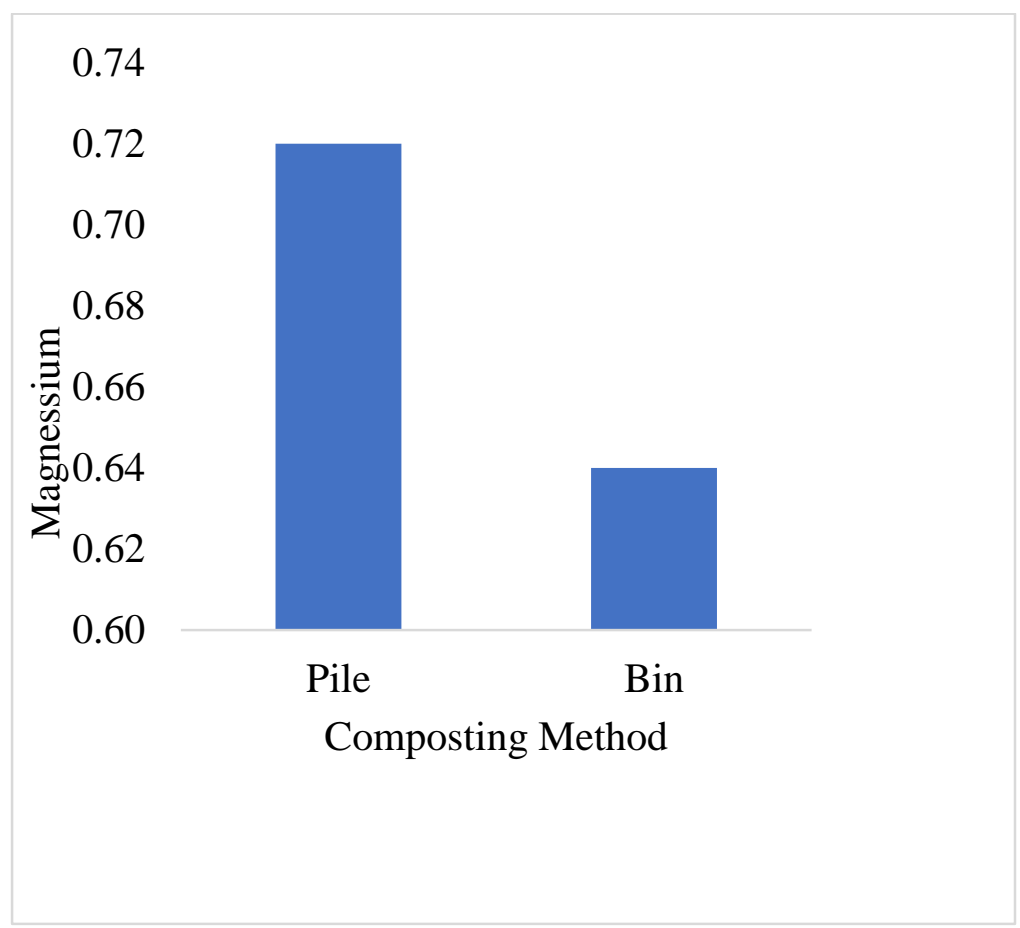

Figure 6: Magnesium content of the two composting methods

The Figure7 indicates the Calcium content for Pile compost was $1.78 \%$ and Bin compost was $1.62 \%$. Calcium content of pile compost was higher.

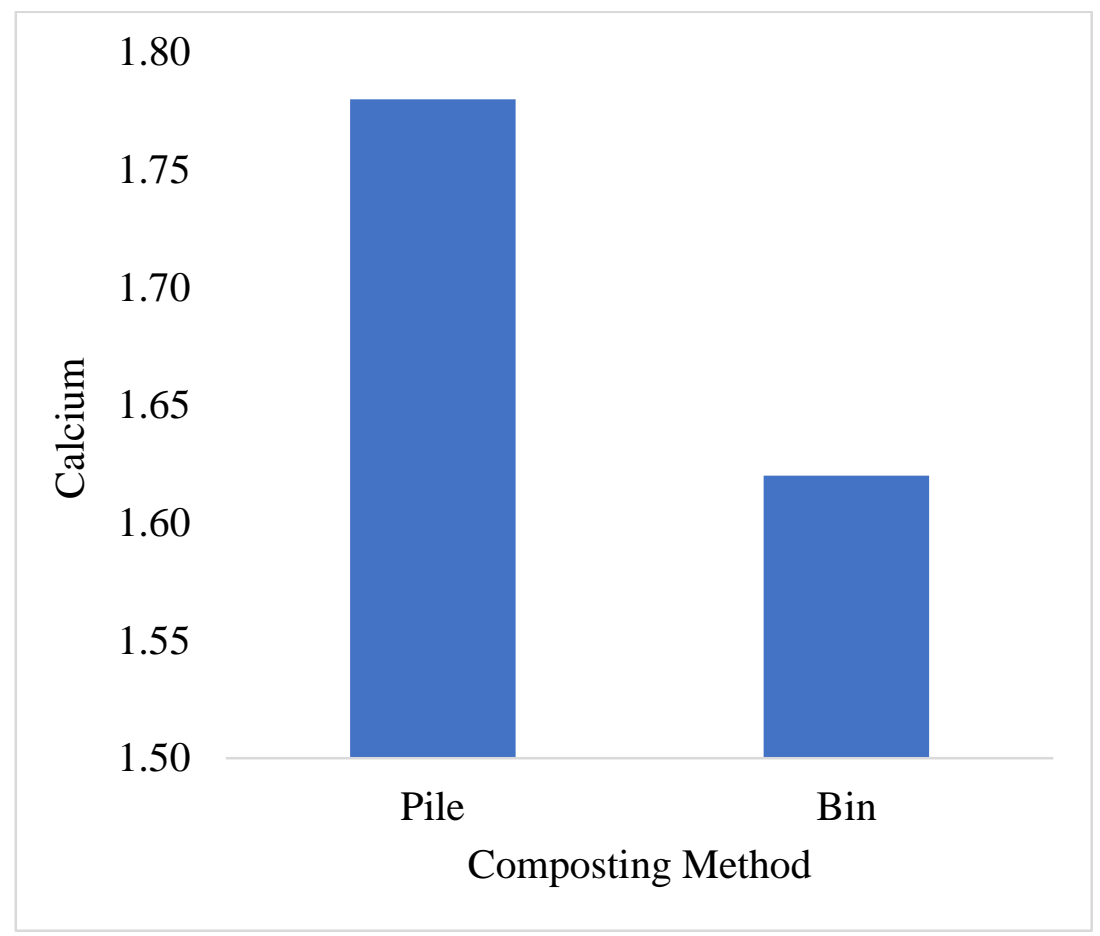

Figure 7: Calcium content of the two composting methods 
Table 1 below illustrates the plant height of the four different growing media. Numbers with the same alphabet indicates that there is no significance $(\mathrm{p}<0.05)$. There was no variation between the mixed pile-bin compost and the pile compost but there was great variation in the bin compost and the control on the height of A. leiocarpus. The control had the lowest plant height of 4.38 while the pile compost had the highest height of 18.48 though there was no variation with the mixed pile and bin compost which was observed to be 16.73 in height.

Table 1: Effects of the Growing Medium on Plant Height

\begin{tabular}{ll}
\hline Treatments & Plant Height \\
\hline Pile and Bin Composting & $16.73^{\mathrm{a}}$ \\
Pile Composting & $18.48^{\mathrm{a}}$ \\
Bin Composting & $14.83^{\mathrm{b}}$ \\
Control & $4.38^{\mathrm{c}}$ \\
SE \pm & 1.08 \\
\hline
\end{tabular}

Means in the same column having the same letters are not significantly different $(p \leq 0.05)$

Table 2 below shows the stem girth of different growing medium. It was observed to be highest in pile compost (2.00) and lowest in the control $(0.37)$. There was high significant difference $(\mathrm{p}<0.05)$ between the pile compost and the other growth medium for the stem girth. There was no variation between the mixed pile- bin compost and the bin compost but there was high variation with the control.

Table 2: Effects of the Growing Medium on Stem Girth

\begin{tabular}{ll}
\hline Treatments & Stem Girth \\
\hline Pile and Bin Composting & $1.70^{\mathrm{b}}$ \\
Pile Composting & $2.00^{\mathrm{a}}$ \\
Bin Composting & $1.58^{\mathrm{b}}$ \\
Control & $0.37^{\mathrm{c}}$ \\
SE \pm & 0.09 \\
\hline
\end{tabular}

Means in the same column having the same letters are not significantly different $(p \leq 0.05)$ 
Table 3 below shows the leaf count of the different growing medium. It was observed to be highest in the mixed pile-bin compost (66.00) and lowest in the control (11.75). There was high significant difference $(p<0.05)$ between all the four other growth mediums for the leaf count.

Table 3: Effects of the Growing Medium on Leaf Count

\begin{tabular}{ll}
\hline Treatments & Leaf Count \\
\hline Pile and Bin Composting & $66.00^{\mathrm{a}}$ \\
Pile Composting & $52.75^{\mathrm{b}}$ \\
Bin Composting & $30.75^{\mathrm{c}}$ \\
Control & $11.75^{\mathrm{d}}$ \\
SE \pm & 3.86 \\
\hline
\end{tabular}

Means in the same column having the same letters are not significantly different $(p \leq 0.05)$

Table 4 and 5 shows independent T-test of proximate composition (pH, Nitrogen, Phosphorus, Potassium, Calcium and Magnesium) between pile and bin composting methods. Pile compost was observed to have the highest values for all the proximate compositions although there was no significant difference between the sericulture compost of the two methods.

Table 4: Proximate Compositions for the pile and bin compost

\begin{tabular}{llllll}
\hline Proximate Composition & Location & N & Mean & Std. Deviation & Std. Error Mean \\
\hline $\mathrm{pH}$ & Pile Compost & 3 & 8.30 & 0.26 & 0.15 \\
& Bin Compost & 3 & 8.20 & 0.10 & 0.06 \\
Nitrogen & Pile Compost & 3 & 0.93 & 0.09 & 0.05 \\
& Bin Compost & 3 & 0.82 & 0.06 & 0.04 \\
Phosphorus & Pile Compost & 3 & 0.89 & 0.08 & 0.05 \\
\multirow{2}{*}{ Potassium } & Bin Compost & 3 & 0.82 & 0.11 & 0.06 \\
\multirow{2}{*}{ Calcium } & Pile Compost & 3 & 0.58 & 0.04 & 0.02 \\
& Bin Compost & 3 & 0.51 & 0.06 & 0.04 \\
\multirow{2}{*}{ Magnesium } & Pile Compost & 3 & 1.78 & 0.11 & 0.06 \\
& Bin Compost & 3 & 1.62 & 0.06 & 0.04 \\
& Pile Compost & 3 & 0.72 & 0.07 & 0.04 \\
\hline
\end{tabular}


Table 5: Independent T-test of Proximate Compositions between Pile and Bin Composting Methods

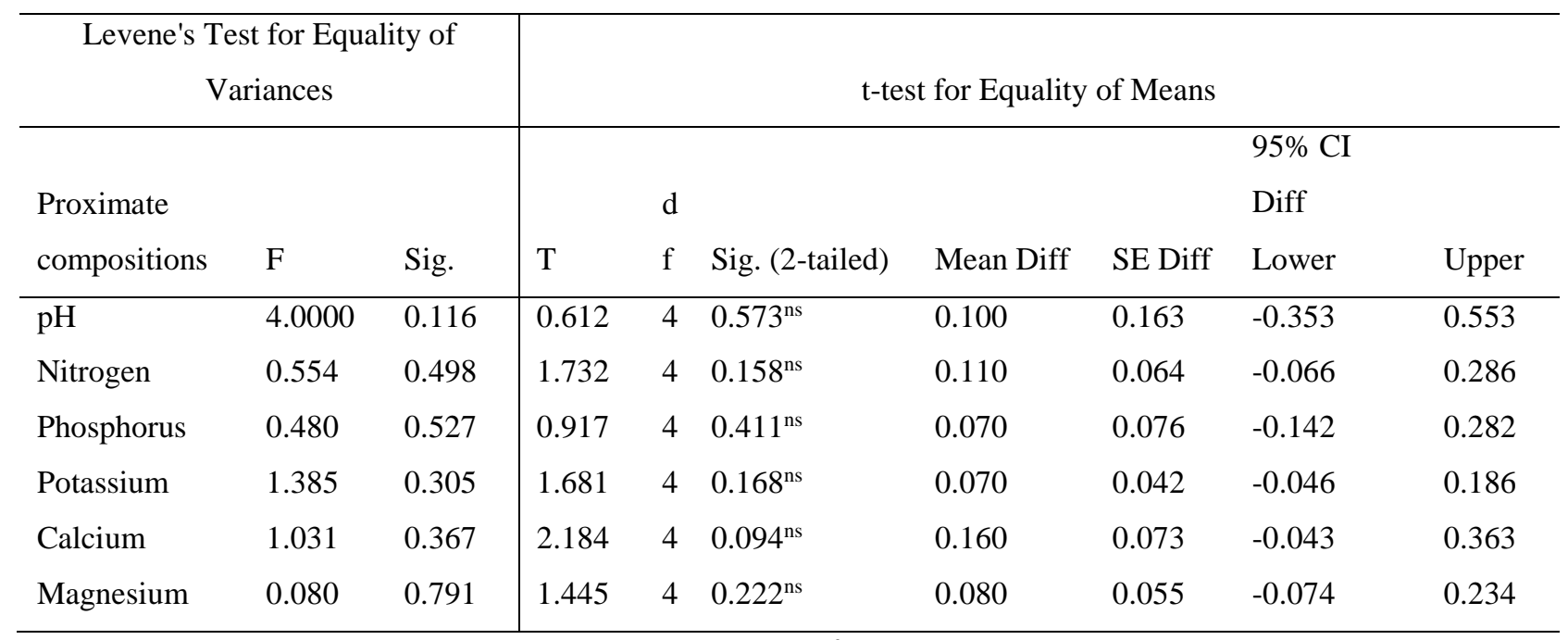

ns not significant

\section{DISCUSSION}

The result obtained in table 4 and 5 revealed that pile compost had the highest mineral compositions (pH, nitrogen, phosphorous, potassium, calcium and magnesium) though there was no significant difference in mineral composition tested at $5 \%$ probability level. $\mathrm{pH}$ of sericulture waste from pile and bin composting method was 8.30 and 8.20 respectively, values are high but not significantly different, these does not agree with findings by Bhat et al(2015) who observed a decrease in pH during the process of composting of a mixture of bagasse and cattle dung which may be due to the mineralization of Nitrogen and Phosphorus compounds and the production of humic and fulvic acid. Composted organic material is being applied on agricultural fields as an amendment to provide nutrients and also to enhance the organic matter content and improve the physical and chemical properties of the cultivated soils. Composted organic material contains essential nutrients for plant growth, especially $\mathrm{N}$ and P (Beltran et al. 2002). Land application of composted material as a fertilizer source not only provides essential nutrients to plants, it also improves soil quality and effectively disposes of wastes.

Nitrogen is known to be a major nutrient required by plants in large quantities for growth and photosynthesis and since it was observed to be have a higher value in the pile compost $(0.93 \%)$, it could be richer and alter the rate of for plant growth and completion of life cycle which agrees with Beltran et al. (2002) who stated that; element can be essential for plant growth if in its absence the plant is unable to complete a normal life cycle. Liebig's law of minimum stated that plant must obtain nitrogen which is a macro-nutrient from the growing media. The result obtained also agrees with findings by Cathy (1992), who emphasized that Nitrogen are rich materials in composting pile.

Potassium which was present for both pile $(0.58 \%)$ and bin $(0.51 \%)$ compost though higher for pile compost, it is also a major nutrient required by plant for increase crop yields, water absorption and retention, strong roots and sturdy stem. Silkworm processed waste material contains a higher concentration of exchangeable potassium due to enhanced microbial activity that increase the rate of mineralization. Suther (2007) observed that the production of acid during decomposition of organic matter by microorganisms is the key mechanism for solubilization of insoluble potassium. 
Phosphorus which was present for both Pile $(0.89 \%)$ and bin $(0.82 \%)$ compost though higher for pile compost though not significant is required by plant for photosynthesis and other nutrient transport. This result agrees with results obtained by Mistry et al. (2001), where phosphate values were relatively high after composting. Available forms of phosphate are performed partly by the activities of microbes in the gut wall of earthworms or silkworms.

Calcium $(\mathrm{Ca} \%)$ had the highest percentage $(1.78 \%$ and $1.62 \%$ for pile and bin respectively) mineral value, it is an essential part of cell wall structure, which provides the plant with normal transport and retention of other elements as well as strength in the plant. It is also thought to counteract the effect of alkali salts and organic acids within a plant. This result is in line with research by Spiers et al. (1986) who reported that earthworms convert Calcium oxalate crystals in ingested fungal hyphal to calcium bicarbonate which is ingested in cast material, which increases calcium availability.

Magnesium which was present and relatively high was recorded to be higher in pile and lower in bin method of composting $(0.72 \%$ and $0.64 \%$ respectively) though with no variation at $5 \%$ level of significance. It is part of the chlorophyll in all green plants and essential for photosynthesis and also helps to activate many plant enzymes needed for growth.

Morphological characteristics are the visually determinable attributes of tree and seedlings to understand their performance in response to different compost/ organic fertilizer application which includes compost of sericulture waste and to adopt them in desirable agro forestry systems (Duguma and Tonye 1994). This study clearly revealed that organic fertilizations yielded better growth and quality of the seedlings of selected agro forestry tree species, i.e. they have beneficial effect on the improvement of growth parameters of seedlings. This result is also supported by the study of Sundralingam 1983; Sanginga et al. 1989; Walker et al. 1993; Bhuiyan et al. 2000, who reported the accelerated growth parameters in response to the application of different fertilizer both organic and chemical on species like, Tectona grandis and Casuarina sp. The beneficial use of organic manure or cow dung for improving growth of leguminous agro forestry tree seedlings are also in accordance with the works of several authors (Das 1984; Paul and Hossain 1996). In some cases, it was evident that the higher doses of organic fertilizers have negative effect on seedlings (i.e. reduced growth) which might hamper the seedling growth by initiation of toxic effects. This supported the findings of Van den Driessche (1980), who reviewed both positive and negative effects of application of nursery fertilizers on subsequent seedling growth and survival. Negative effects of organic fertilization were also reported for Sitka spruce (Benzian et al. 1974) and Lobolly pine (Pharis and Kramer 1964; Schomaker 1969). Similarly, Kadeba (1978) and Hartley (1977) reported that an addition of access fertilizer on Pinus caribaea depressed growth and increased mortality of the seedlings.

The results obtained (Table 1-3) revealed that the pile method of composting sericulture had the highest germination rate for plant height and the stem girth while the mixed pile-bin method recorded the highest value for leaf count, followed by the bin method. It was observed that the first visible growth of the control was at the $12^{\text {th }}$ week and based on the statistical analysis obtained it was observed that compost generated from the pile method showed high variation in terms of stem girth and plant height, while the mixture of compost from pile-bin compost had the highest leaf count which could have also been as a result of the combination with pile compost, hence it may be deduced that the pile method of composting helps to hasten the growth of Anogeissus leiocarpus which is known to have a slow growth rate and slow percentage germination rate. The percentage germination rate of Anoigessus leiocarpus seeds planted showed that $70 \%$ of seeds germinated in the pile compost, $30 \%$ of 
seeds in the bin compost, $40 \%$ in the mixed pile-bin compost and $10 \%$ in the control. Seeds that grew using the pile compost had the first emergence after 8 weeks of planting, followed by the mixed pile-bin compost then the bin compost which was after 9 weeks of planting, the control germinated after 12 weeks of planting. The beneficial use of organic manure for improving growth of agroforestry tree seedling is also in accordance with the works of several authors (Paul and Hossain 1996).

\section{CONCLUSION}

The experiment evaluated the effect of compost quality of sericulture waste on the growth of Anogeissus leiocarpus using two composting method. The selected composting method involves pile composting and bin composting. At the end of the composting process, it was concluded that pile compost gave the highest percentage in Nitrogen (0.93\%), Potassium (0.58\%), Phosphorus (0.089\%), Calcium (1.78\%), and Magnesium (0.72\%); and when the compost was subjected to Anogeissus leiocarpus seeds, the pile compost gave the highest plant height and stem girth while the mixed pile-bin compost gave the highest leaf count. Compost helps in the growth of plants as observed in A. leiocarpus which has slow growth and germination percentage.

\section{RECOMMENDATION}

Based on the result of the analysis and outcome of the findings, pile composting method is best recommended for composting of sericulture waste and growth of A. leiocarpus seeds. This will enhance the maximum production and domestication of economically and environmentally valued tree plantation establishment. It will also help in management of sericulture waste by reducing or preventing pollution which is an environmental hazard. Furthermore, research can be conducted by introducing earthworm, leaf litters and kitchen waste using the pile and bin method of composting and other plant species can be grown with these composted soils. 


\section{REFERENCES}

Agaie, B. M., and Onyelli.P. A. (2007). Anthelmintic activity of the crude aqueous leaf extracts of Anogeissus leiocarpus in sheep African Journal of Biotechnology, 13: 151 - 1515.

Agunwamba, J.C., Egbuniwe, N., and Ogwueleka, T.C. (2003). Least cost management of Solid waste collection. The journal of solid waste technology and management, 29 (3): 122 -148.

AitBaddi, G., Hafidi, M., and Cegarra, J. (2004). Characterization of fill vie acids by elemental \& spectroscopic (FTIR and 13C-NMR) analyses during composting of olive mill wastes plus straw. Bioresource Technology, 93: 285-290.

Armjio de Vega C., Ojeda Benitez S., and Ramirez Barreto, M.E. (2008). Solid waste characterization and recycling potential for a University campus. Waste Management, Suppll: S21-6 Epub.

Ashiru M. 0. (2000). Mulberry Sericulture; A suitable farmer friendly vocation for the Nigerian peasant farmers: present status, problems and suggested solutions. A paper presented at the National Workshop on Agriculture and Rural Development in Nigeria, Forestry Research Institute of Nigeria, Ibadan, Oyo state.

Ashiru, M. O. (1986): Silkworm as Money Spinners: Anaphevs Bombx; status report in Nigeria. Paper presented at the Nigeria field society held at the School of Forestry, Ibadan.

Berrahmouni, N., and Secandi, M. (2004). Africa's Great Green Wall Initiatives: a model for restoration success. Geophysical Research Abstracts, 16, EGU204 - 1521, EGU General Assembly Vienna, Austria.

Bhat, S.A., Singh, J., and Vig, A.P. (2015). Potential Utilization of bagasse as feed material for earthworm Eisenia foetida and production of vermicompost, springer Plus, 4: 11, 1-9

Bicudo, J.R., and Westerman, P.W. (2005). Management considerations for organic waste use in agriculture. Bioresource Technology, 96:215-221

Bognainwu, F., Thiombiano, A, Oden, P. C., and Guinko, S. (2000). Seed province and latitudinal gradient effects onseed germination capacity and seeding establishment of fire indigenous species in Burkina Faso, Tropical Ecology, 51: 207 - 220.

Chabbi, M, Benayache, S. Benayache, F., N., Gom S. Kone, M., Anton, R., Weniker, B., and Lobstein, A. (2008). Triterpenes andpolyphenous from Anogeissusleiocarpus (combretaceae) Biochemical systematics and Ecology, 36:59 - 62.

Cherry R. (1993). Sericulture. Bull Entomology Society Company, New York, 35:83-84.

Dandin, S.B., and Kumar, S.N. (2007). Biomedical uses of silk and its derivatives. Indian silk, 45 (9): 5-8.

Dias, V. (2006). Investigation of the poor Germination ofAnogeissus leiocarpus, M,ScDissertion, Ghentt University.

Dutta, B.M. (2006). Eco- Friendly approach in sericulture. Indian silk, 45(4): 24-26.

Gahlot, N.S., and Suryanarayana, N. (2008). Utilization of secondary waste products of silk industry, Paper presented at International conference on exploitation of agricultural and food industry by-products and waste material through 'the application of processing techniques, Bucharest.

Ganopadhyay, D. (2008). Sericulture industry in India - A review, India Science and Technology, Geneva, Switzerland: International Organization for Standardization.

Hatten, X. R., Borazhani, H., and Diehl, S. (2005). Leaching of Nitrogen, Phosphorous and Potassium from Sawdust amended with chicken litter. Proceedings of Mississippi Water Resources Conference. 
IRBET (CTFT) (1983). Fiche monographicquie - Bilande (A monograph on) Anogeissus leiocarpus scientifigue et Technologgique (CNRST), Ovagadougou.

Kelly, B. A. (2011). Grown, response of Anogeissus leiocarpus copies to prescribed fire and weeding after plantation harvesting in the Sudanian zone of Mali, West Africa. Africa Journal of Plant Science, 2, $92-101$.

Nasholm, T, Kielland, K., and Ganeteg, U. (2009). Uptake of organic nitrogen by plants. New Phytologist, 182: $31-48$.

Nosb (2006). The National Organic Standard Board (NOSB), the future of organic food and farming in the United States.

Okonko, I. O., Ogun, A. A., Shittu, O. B., and Ogunnusi, T. A., (2009). Waste utilization as means of ensuring environmental safety- An Overview, Electronic journal of environment agricultural and food chemistry, 8(9): $836-855$.

Okonko, I. O., Olabode, O. P., and Okeleji, O. S. (2006). The role of biotechnology in the socioeconomic advancement and national development: An overview. African J. Biotechnology 5 (19): 23: 54 2366.

Sacande, M., and Sanogo, S. (2007). Anogeissus leiocarpus (DC.) Guill. \& Perr. Seed Leaflet N ${ }^{0} 119$, Forest \& Landscape Denmark.

Sanchez -Monedero, M. A., Roig, A., Paredes, C., and Bema J. M. P. (2001). Nitrogen transformation during organic waste composting by the Rutgers system and its effects on $\mathrm{pH}, \mathrm{EC}$ and maturity of the compositing mixtures. Bioresource Technology, 78: 301 -308.

Some, L. M., Gamene, C. S., and Verwey, H. (1989). A study of the causes of poor germination of Anogeissus leiocarpus seeds. In Tropical Tree Seed Research, ACIAR proceedings of an international workshop held at the Forestry Training Center, 28:37-40

Sundralingam P. (1983). Responses of potted seedlings of Dryobalanop aromatica and Dryobalanops oblongifolia to commercial fertilizers. Malaysian Forester, 46: 86-92.

Uddin, M. B., Khan, M., Mukul, S.A., and Hossain, M.K. (2008). Effects of inorganic fertilizers on biological nitrogen fixation and seedling growth of some agro forestry trees in Bangladesh. Journal of Forestry Research, 19: 303-306.

Uddin, M. B., Khan, M., Mukul, S.A., and Hossain, M.K. (2007). Effects of phosphorous fertilizer on seedlings growth and nodulation capabilities of some popular agroforestry tree species of Bangladesh. Journal of Forestry Research, 18: 283-286.

Uddin, M. B., Khan, M., Mukul, S.A., and Hossain, M.K. (2009). Seedling response of three agroforestry tree species to phosphorous fertilizer application in Bangladesh: growth and nodulation capabilities. Journal of Forestry Research, 20: 45-48. 